\title{
The Amount of Shares Held by Chaebol's Other Affiliated Firms and Affiliated Firm's Ownership- Control Disparity: A Cross-Sectional Analysis
}

\author{
JAE-HYUNG LEE ${ }^{*}$ AND MYUNG HOON YI ${ }^{* *}$
}

We examine the relationship between the amount of shares held by Chaebol's other affiliated firms and affiliated firm's ownership-control disparity. To this end, the ownership-control disparity equations are estimated with the ownershipcontrol disparity index and the voting right leverage index as dependent variables, using cross-sectional data on 78 affiliated firms in Chaebols in 2005. These Chaebols are controlled by the ceiling on the total amount of holding shares of other affiliated firms in Chaebol. The estimation results with the ownership-control disparity index indicate that the increase in the amount of shares held by Chaebol's other affiliated firms deepens the ownership-control disparity. And the amount of net assets and the amount of cash flow mitigate the ownership-control disparity. The estimation results of the voting right leverage index are almost the same as those of the ownership-control disparity index. We also find that the ownership-control disparity index is more elastic than the voting right leverage index with respect to the amount of shares held by Chaebol's other affiliated firms. Overall, these empirical findings suggest that the ceiling on the total amount of holding shares of other affiliated firms in Chaebol can contribute to the desirable corporate governance.

Keyuords: the amount of shares held by Chaebol's other affiliated firms, ownership-control disparity index, voting right leverage index, the ceiling on the total amount of holding shares of other affiliated firms in Chaebol

Jae-Hyung Lee, Associate Professor, The Brain Korea 21, Department of Economics. Scoul National Iniversity. Jae-Hyung lee was partially supported by the Second Brain Korea 21 project in ?007. The Korea kair Trade Commission provides data and detailed information abeut the data used in this study.

${ }^{* *}$ Corresponding author, Myung Hoon Yi, Professor, Department of Economics, Myongii Iniversity; Namgajwa 2-dong, Seodaemun-gu, Seoul, Korea, 120-728; Tel: +82-2-30()-(1)685; Fax: - $32-2-30()-$ 065 - 


\section{INTRODUCTION} $\prod$ he ownership-control disparity has been a critical issue for the last twenty the total amount of holding shares of other affiliated firms in Chaebol to mitigate the ownership-control disparity. However, Chaebols are opposed to this ceiling system because this ceiling system has little effect on the ownership-control disparity. This issue has hardly been studied in Korea. In this respect, our paper tries to rigorously tackle this issue empirically.

The degree of distortion of the ownership-control relationship is measured by the ownership-control disparity index or the voting right leverage index. The ownership-control disparity index is defined as the fraction of shares for Chaebol's voting right minus the fraction of shares owned by Chaebol, and the voting right leverage index is defined as the fraction of shares for Chaebol's voting right divided by the fraction of shares owned by Chaebol.

The higher value of the ownership-control disparity index or the voting right leverage index means a severe distortion of the ownership-control relationship exists. For example, the average ownership-control disparity index is $3.84 \% \mathrm{P}$ for thirteen European countries (Austria, Belgium, Finland, France, Germany, Ireland, Italy, Norway, Portugal, Spain, Sweden, Swiss, U.K.) as of 2005, whereas the average ownership-control disparity index for 78 affiliated firms in Korean Chaebols is $50.33 \%$ P. This implies that Korean Chaebols have a higher level of voting right than the firms in the thirteen European countries.

The Chaebol's exercise of voting right with the shareholdings by Chaebol's other affiliated firms may disturb the property right of the minority shareholders. This causes the conflict of interests between controlling shareholder and minority shareholders. The ceiling on the total amount of shares held by Chaebol's other affiliated firms is expected to mitigate the affiliated firm's ownership-control disparity (Kang and Lee 2007). Ko et al. (2006) assert that the ceiling on the total amount of shares held by Chaebol's other affiliated firms has a negative effect on the investment.

The purpose of the paper is to examine the relationship between the amount of shares held by Chaebol's other affiliated firms and affiliated firm's ownership-control disparity. To this end, the ownership-control disparity equations are estimated with the ownership-control disparity index and the voting right leverage index as dependent variables, using cross-sectional data on 78 affiliated firms in Chaebols in 2005. These Chacborls are subject to a ceiling on the total amount of holding shares of other affiliated firms in Chaebnl.!

Also we compare the elasticity of the ownership-control disparity index to the elasticity of the voting right leverage index with respect to the amount of shares held by Chaebul's other affiliated firmmsloaded from Brill.come4/26/2023 11:01:00AM 
Gerdtham and Jonsson (1991) assert that the outliers can produce a misinterpretation on the estimated regression equation. Therefore, we also estimate the regression equation with data excluding outliers.

The structure of the paper is as follows. Section II develops the analytical model that highlights the effect of the amount of shares held by Chaebol's other affiliated firms on affiliated firm's ownership-control disparity. Section III describes the data, and the empirical results are presented and discussed in Section IV. Section V concludes.

\section{MODEL}

To examine whether the increase in the amount of shares held by Chaebol's other affiliated firms distorts affiliated firm is ownership-control relationship, we set the following ownership-control disparity equation,

$$
\operatorname{DISTORTION}_{i}=\mathrm{f}\left[(\mathrm{SHED} / \mathrm{K})_{i},(\mathrm{Z} / \mathrm{K})_{i}\right]
$$

where DISTORTION stands for the ownership-control disparity index (DISPARITY) or the voting right leverage index (VRLI). SHED and $K$ denote the amount of shares held by Chatbol's other affiliated firms and the amount of capital, respectively. Vector $Z$ includes the control variables: the amount of net assets (NA), the amount of sales revenue (S), the amount of debt (D), and the amount of cash flow (CF). CF is defined as the sum of the amount of net profit and the amount of depreciation.

The estimated Spearman correlation coefficient between $\mathrm{K}$ and each of the explanatory variables is very high. For example, the estimated Spearman correlation coefficients between $\mathrm{K}$ and $\mathrm{NA}$ and $\mathrm{K}$ and $\mathrm{CF}$ are 0.908 and 0.946 , respectively, which is significant at the $1 \%$ level. Therefore, to avoid possible multicollinearity, all of the explanatory variables are divided by $\mathrm{K}$. Hence, SHED/K indicates the amount of shares held by Chaebol's other affiliated firms divided by the amount of capital.

Since the increase in the amount of shares held by Chaebol's other affiliated firms may strengthen Chatbrl's controlling power relative to ownership and thus deepen the ownership-control disparity, the estimated coefficient of SHED/K is expected to be positive. The estimated coefficient of $N A / K$ is expected to be negative, since the increase in the amount of net asset may mitigate the ownership-control disparity due to severe governmental regulation. An affiliated firm with higher level of cash flow will increase the fraction of shares owned by Chaebol and thus reduce the ownership-control disparity. Therefore, the estimated coefficient of $\mathrm{CF} / \mathrm{K}$ is expected to be negarive. 


\section{DATA}

The data on the ownership-control disparity index (DISPARITY), the voting right leverage index (VRLI), the amount of shares held by Chaebol's other affiliated firms (SHED) and the amount of net assets (NA) come from the Korea Fair Trade Commission (KFTC). The data on the amount of capital (K), the amount of sales revenue (S), the amount of debt (D), the amount of net profit (NP), the amount of depreciation (DEP), and the amount of cash flow (CF) are derived from the Korea Financial Supervisory Service (KFSS).

Table 1. Definition and SOURCe of Variables

\begin{tabular}{|c|c|c|c|}
\hline Variable & $\begin{array}{l}\text { Definition of Variables } \\
\text { (Source) }\end{array}$ & $\begin{array}{l}\text { Mean } \\
(\mathrm{SD})\end{array}$ & $\begin{array}{l}\text { Runs Test } \\
\text { (p-value) }\end{array}$ \\
\hline DISPARITY ${ }^{11}$ & $\begin{array}{l}\text { The index of ownership-control disparity } \\
\text { (KFTC) }\end{array}$ & $\begin{array}{r}50.325 \\
(35.568)\end{array}$ & $\begin{array}{l}\text { Accept } \mathrm{H}_{0} \\
(0.254)\end{array}$ \\
\hline VRUII & $\begin{array}{l}\text { The voting right leverage index } \\
\text { (KFTC) }\end{array}$ & $\begin{array}{r}86.887 \\
(375.895) \\
\end{array}$ & $\begin{array}{c}\text { Accept } \mathrm{H}_{0} \\
(0.565) \\
\end{array}$ \\
\hline $\mathrm{SHED}^{2)}$ & $\begin{array}{l}\text { The amount of money share-holded from other } \\
\text { affiliated firms by Chaebol (KFTC) }\end{array}$ & $\begin{array}{c}62.455 \\
(114.212)\end{array}$ & $\begin{array}{l}\text { Accept } \mathrm{H}_{0} \\
(0.254)\end{array}$ \\
\hline $\mathrm{K}^{23}$ & $\begin{array}{l}\text { The amount of equity } \\
\text { (KFSS) }\end{array}$ & $\begin{array}{r}994.916 \\
(2358.156) \\
\end{array}$ & $\begin{array}{c}\text { Accept } \mathrm{H}_{i} \\
(0.648) \\
\end{array}$ \\
\hline $\mathrm{NA}^{2}$ & $\begin{array}{l}\text { The amount of net asset } \\
\text { (KFTC) }\end{array}$ & $\begin{array}{c}697.474 \\
(1884.363)\end{array}$ & $\begin{array}{l}\text { Accept } \mathrm{H}_{0} \\
(0.494)\end{array}$ \\
\hline$S^{2)}$ & $\begin{array}{l}\text { The amount of sales revenue } \\
\text { (KFSS) }\end{array}$ & $\begin{array}{l}1907.875 \\
(4459.085)\end{array}$ & $\begin{array}{l}\text { Accept } \mathrm{H}_{0} \\
(0.254)\end{array}$ \\
\hline $\mathrm{D}^{2)}$ & $\begin{array}{l}\text { The amount of liability } \\
\text { (KFSS) }\end{array}$ & $\begin{array}{c}1075.073 \\
(1967.950)\end{array}$ & $\begin{array}{c}\text { Accept } \mathrm{H}_{0} \\
(0.362)\end{array}$ \\
\hline $\mathrm{NP}^{2)}$ & $\begin{array}{l}\text { The amount of net profit } \\
\text { (KFSS) }\end{array}$ & $\begin{array}{c}169.394 \\
(448.698)\end{array}$ & $\begin{array}{l}\text { Reject } \mathrm{H}_{0} \\
(0.006)\end{array}$ \\
\hline $\mathrm{DEP}^{21}$ & $\begin{array}{l}\text { The amount of depreciation } \\
\text { (KFSS) }\end{array}$ & $\begin{array}{c}75.673 \\
(217.020)\end{array}$ & $\begin{array}{l}\text { Accept } \mathrm{H}_{0} \\
(0.171)\end{array}$ \\
\hline $\mathrm{CF}^{2 \prime}$ & $\begin{array}{l}\text { The amount of cash flow } \\
\text { (KFSS) }\end{array}$ & $\begin{array}{l}215.068 \\
(635.600)\end{array}$ & $\begin{array}{c}\text { Accept } H_{0} \\
(0.171)\end{array}$ \\
\hline
\end{tabular}

Note: 1) Winit: oP for DISPARITY and multiple for VRLI. For more details on the two variables see KPTC (hetp://ftc.go.kr).

2) Inits: one billion Korean Won. CF $=N P+D E P$.

3) $\mathrm{H}_{11}$ : sequence generated by a random process, $\mathrm{H}_{\text {i }}$ : secuence gencrated by a process containing persistence. cut point $=$ median. Hypothesis tests are performed at the $5 \%$ significant level.

Chaebol's 194 non-financial affiliated firms, which are listed on the stock market, are subject to a ceiling on the total amount of shareholdings by Chaebol's other affiliated firms as of 2005. The cross-sectional data on Chaebol's 78 affiliated 
firms out of 194 affiliated firms are available for the period of 2005 .

Details of the data sources as well as means and standard deviations (SDs) of the variables are given in Table 1 .

Given that the estimators are sensitive to the assumption of normality (Pagan and Vella 1989), the runs tests are performed for the selected variables. The runs tests show that, with one exception, all the variables (NP) are generated by a random process.

With insufficient cross-sectional data on 78 affiliated firms, the power of the test will depend on the way in which the observations are ordered (Gerdtham and Jonsson 1991). The order of the data is from the data package of the "2005 Amount of Shareholdings by Affiliated Firms in Chaebol" provided by the KFTC.

Since the voting right leverage index is not defined when the fraction of shares owned by Chaebol is zero, the corresponding observations are deleted when estimating ownership-control disparity equation with the voting right leverage index. In this case, the number of observations reduces from 78 to 49. We also estimate the regression equation with data excluding outliers.

\section{ESTIMATION RESULTS}

In this section, we empirically investigate the relationship between the amount of shares held by Chaebol's other affiliated firms and the ownership-control disparity.

As a test for misspecification, we use Ramsey's RESET tests. It assumes that the effect of omitted variables can be proxied by some function of the original regressors. The regression results presented in Table 2 under the column "RESET" suggest that the null hypothesis of functional form misspecification is rejected in the two ownership-control disparity equations.

On the other hand, the observed Durbin-Watson (D.W.) statistic lies between the tabulated upper boundary value (D.W.u) and the value of 4-D.W.u, implying that correct specifications are made in the two estimated regression equations. Based upon the observed D.W. value, it can be concluded that the order of data on the affiliated firms is appropriate.

From the reported regressions provided in Table 2 under the column "Homoskedasticity", heteroskedasticity is not detected in the two estimated regressions. It can be found from Table 2 that the two estimated equations may adequately describe the behavioral relationship.

In Table 3, the Spearman correlation coefficient between DISPARITY and SHED $/ K$ is 0.367 , and the correlation coefficient between VRLI and SHED/K is 0.086 . These results indicate positive correlations between DISPARITY and $\mathrm{SHED} / \mathrm{K}$ and between VRLI and $\mathrm{SHED} / \mathrm{K}$, although the correlation coefficient between VRLI and SHED/K is close to zerOownloaded from Brill.com04/26/2023 11:01:00AM 
Table 2. Diagnostic Evaluation of Each Ownership-Control Disparity EQLATION"

\begin{tabular}{c|c|c|c|c|c|c}
\hline \multirow{2}{*}{ Ownership-Control } & \multicolumn{5}{|c|}{ Test for Functinal Form Misspecification } & $\begin{array}{c}\text { Homo- } \\
\text { skedasticity }\end{array}$ \\
\cline { 2 - 7 } Disparity Equation & RESET2 & RESET3 & $\mathrm{R}^{2}$ & D.W. & $\mathrm{F}(5,72)$ & $\chi^{2}(5)$ \\
\hline DISPARITY & $\mathrm{t}=1.328$ & $\mathrm{t}=2.010^{* *}$ & 0.280 & 1.795 & $5.597^{* * *}$ & 5.538 \\
\hline VRLI & $\mathrm{t}=0.771$ & $\mathrm{t}=0.582$ & 0.035 & 2.105 & 0.310 & 0.539 \\
\hline
\end{tabular}

Note: 1) The number of observations for DISPARITY is 78 and those for VRLI is 49 . For the test procedure see Dowrick (1993). ***,**, and * indicate significance at the $1 \%, 5 \%$, and $10 \%$ levels, respectively.

2) For the test procedure, see Breusch and Pagan (1979). The $90 \%$ critical value for $\chi^{2}(5)$ is 9.236 .

Table 3 Pearson Nonparametric Correlations among Selected Variables ${ }^{\text {1) }}$

\begin{tabular}{c|c|c|c|c|c|c|c}
\hline Ownership-Control & \multicolumn{7}{|c}{ Explanatory Variables } \\
\cline { 2 - 9 } Disparity Variables & DISPARITY & VRLI & SHED/K & NA/K & S/K & D/K & CF/K \\
\hline DISPARITY & - & $0.284^{* *}$ & $0.367^{* * *}$ & $-0.408^{* * *}$ & -0.048 & 0.121 & -0.169 \\
\hline VRLI & $0.284^{* *}$ & - & 0.086 & -0.007 & -0.113 & -0.040 & -0.098 \\
\hline
\end{tabular}

Note: 1) For the definition of variables see Table 1.

2) The number of observations for DISPARITY is 78 and those for VRLI is 49. For the test procedure see Dowrick (1993).***,**, and * indicate significance at the $1 \%, 5 \%$, and $10 \%$ levels, respectively.

Table 4 presents the OLS estimation results for the ownership-control disparity equation with the ownership-control disparity index. In column "(2)", the estimated coefficient of SHED $/ \mathrm{K}$ is 0.206 and is significant at the $1 \%$ level, whereas the estimated coefficient of SHED/K is insignificant in column "(1)." In the columns "(3)" and "(4)" we deleted the outliers of 61st and 65th firms, on the basis of the casewise diagnostics. Outliers are points whose standardized residual is greater than 3.3.2 Then, the estimated coefficients of SHED/K are 0.714 and 0.715 , respectively, and are significant at the $1 \%$ level. These results suggest that the large amount of shares held by Chaebol's other affiliated firms leads to stronger Chaebrl's controlling power relative to ownership and thus deepens the ownership-control disparity. Therefore the ceiling on the total amount of shares held by Chaebrl's other affiliated firms can contribute to reducing the ownership-control disparity.

The estimated coefficients of $\mathrm{NA} / \mathrm{K}$ are negative and significant at the $1 \%$ level in all columns "(1)"-"(4)." The increase in the amount of net asset may mitigate the ownership-control disparity, because firms with large amount of net assets are subject to severe governmental regulation. ${ }^{3}$ The estimated coefficients of $\mathrm{D} / \mathrm{K}$ are insignificant in columns "(1)" and "(3)." Although the estimated

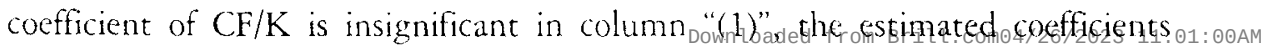


of $\mathrm{CF} / \mathrm{K}$ are negative and significant at the $5 \%$ level in the columns "(3)"-"(4)."4

Tabie 4. The EFfect of SHED/K on OWnership-Control Disparity I

\begin{tabular}{|c|c|c|c|c|}
\hline \multirow{2}{*}{$\begin{array}{c}\text { Explanatory } \\
\text { Variables }\end{array}$} & \multicolumn{4}{|c|}{ Dependent Variable: DISPARITY } \\
\hline & $\begin{array}{c}(1) \\
\mathrm{n}=78\end{array}$ & $\begin{array}{c}(2) \\
\mathbf{n}=78\end{array}$ & $\begin{array}{c}(3) \\
\mathbf{n}=76\end{array}$ & $\begin{array}{c}(4) \\
\mathrm{n}=76\end{array}$ \\
\hline $\mathrm{SHED} / \mathrm{K}$ & $\begin{array}{c}0.144 \\
(0.091) \\
\end{array}$ & $\begin{array}{c}0.206 \\
(0.077)^{* * *}\end{array}$ & $\begin{array}{c}0.714 \\
(0.172)^{* * *}\end{array}$ & $\begin{array}{c}0.715 \\
(0.155)^{* * *}\end{array}$ \\
\hline $\mathrm{NA} / \mathrm{K}$ & $\begin{array}{l}-0.373 \\
(0.119)^{* * *}\end{array}$ & $\begin{array}{l}-0.329 \\
(0.113)^{* * *}\end{array}$ & $\begin{array}{l}-0.372 \\
(0.111)^{* * *}\end{array}$ & $\begin{array}{l}-0.372 \\
(0.110)^{* * *}\end{array}$ \\
\hline $\mathrm{S} / \mathrm{K}$ & $\begin{array}{l}-0.031 \\
(0.015)^{* *}\end{array}$ & $\begin{array}{l}-0.015 \\
(0.010)\end{array}$ & $\begin{array}{l}-0.013 \\
(0.015)\end{array}$ & $\begin{array}{l}-0.013 \\
(0.009)\end{array}$ \\
\hline $\mathrm{D} / \mathrm{K}$ & $\begin{array}{c}0.036 \\
(0.022) \\
\end{array}$ & - & $\begin{array}{c}0.001 \\
(0.023) \\
\end{array}$ & - \\
\hline $\mathrm{CF} / \mathrm{K}$ & $\begin{array}{l}-0.076 \\
(0.159) \\
\end{array}$ & - & $\begin{array}{l}-0.434 \\
(0.175)^{* *}\end{array}$ & $\begin{array}{l}-0.434 \\
(0.160)^{* * *}\end{array}$ \\
\hline constant & $\begin{array}{l}75.293 \\
(11.130)^{* * *}\end{array}$ & $\begin{array}{l}72.200 \\
(9.389)^{* * *}\end{array}$ & $\begin{array}{l}75.215 \\
(10.363)^{* * *} \\
\end{array}$ & $\begin{array}{c}75.220) \\
(10.256)^{* * *}\end{array}$ \\
\hline $\mathrm{R}^{2}$ & 0.280 & 0.246 & 0.370 & 0.370 \\
\hline D.W. & 1.795 & 1.807 & 1.838 & 1.838 \\
\hline $\mathrm{F}$ & $(5,72)=5.597^{* * *}$ & $(3,74)=8.063^{* * *}$ & $(5,70)=8.240^{* * *}$ & $(4,71)=10.447^{* * *}$ \\
\hline SEE & 31.213 & 31.497 & 28.823 & 28.619 \\
\hline
\end{tabular}

Note: 1) Values in parentheses are the standard errors of the estimated coefficients. $* * *, * *$, and * indicate significance at the $1 \%, 5 \%$, and $10 \%$ levels, respectively.

2) The values of D.W.1 and 4-D.W.F with 5 explanatory variables and 75 number of observations at the $5 \%$ significance level are 1.770 and 2.230 , respectively.

3) On the basis of the casewise diagnostics, the outliers of 61 st and 65th atfiliated firms are deleted in the columns "(3)" and "(1)."

Table 5 presents the OLS estimation results for the ownership-control disparity equation with the voting right leverage index. The regression results in Table 5 are almost the same as those in Table 4.

In Table 5, although the estimated coefficient of $S H E D / K$ is insignificant in columns "(1)"."(2)", they are 1.451 and 1.385 and significant at the $1 \%$ level in columns "(3)"-"(4)", where the outliers of the $55 \mathrm{th}$, 68th and $7.4 \mathrm{th}$ firms are deleted on the basis of the casewise diagnostics. These results also suggest that the ceiling on the total amount of holding shares of other atfiliated firms in Chatersl can contribute to reducing the ownership-control disparity.

In columns "(3)"-"(4)", the estimated coefficients of $N A / K$ are negative and significant at the $1 \%$ level. The estimated coefficients of $\mathrm{D} / \mathrm{K}$ are negative and significant in columns " $(3)$ "-" $(4)$ " at the $10 \%$ and $5 \%$ level, respectively. The coefficients of $\mathrm{CF} / \mathrm{K}$ are negative and significant at the $5 \%$ and $1 \%$ levels in columns "(3)"-"(4)”, respectively. 
Table 5. The Effect of Shed/K on OwNership-Control Dispartity II

\begin{tabular}{|c|c|c|c|c|}
\hline \multirow{2}{*}{$\begin{array}{c}\text { Explanatory } \\
\text { Variables }\end{array}$} & \multicolumn{4}{|c|}{ Dependent Variable: VRLI } \\
\hline & $\begin{array}{c}\text { (1) } \\
\mathbf{n}=49\end{array}$ & $\begin{array}{c}(2) \\
\mathrm{n}=49\end{array}$ & $\begin{array}{c}(3) \\
\mathrm{n}=46\end{array}$ & $\begin{array}{c}\text { (4) } \\
\mathrm{n}=46\end{array}$ \\
\hline SHED/K & $\begin{array}{r}1.515 \\
(2.895) \\
\end{array}$ & $\begin{array}{r}1.205 \\
(2.468) \\
\end{array}$ & ${ }^{1.451}(0.219)^{* * *}$ & $\begin{array}{c}1.385 \\
(0.194)^{* * *}\end{array}$ \\
\hline $\mathrm{NA} / \mathrm{K}$ & $\begin{array}{l}-0.905 \\
(2.187) \\
\end{array}$ & $\begin{array}{c}0.025 \\
(1.834) \\
\end{array}$ & $\begin{array}{l}-0.449 \\
(0.165)^{* * *}\end{array}$ & $\begin{array}{l}-0.459 \\
(0.163)^{* *}\end{array}$ \\
\hline $\mathrm{S} / \mathrm{K}$ & $\begin{array}{l}-0.057 \\
(0.248) \\
\end{array}$ & $\begin{array}{l}-0.113 \\
(0.161) \\
\end{array}$ & $\begin{array}{c}0.012 \\
(0.019) \\
\end{array}$ & - \\
\hline $\mathrm{D} / \mathrm{K}$ & $\begin{array}{l}-0.115 \\
(0.360) \\
\end{array}$ & - & $\begin{array}{l}-0.054 \\
(0.027)^{*}\end{array}$ & $\begin{array}{l}-0.041 \\
(0.018)^{* *}\end{array}$ \\
\hline $\mathrm{CF} / \mathrm{K}$ & $\begin{array}{l}-2.480 \\
(2.934) \\
\end{array}$ & - & $\begin{array}{l}-0.600 \\
(0.225)^{* *}\end{array}$ & $\begin{array}{l}-0.553 \\
(0.212)^{* *}\end{array}$ \\
\hline constant & $\begin{array}{r}230.174 \\
(239.215) \\
\end{array}$ & $\begin{array}{r}103.759 \\
(183.134) \\
\end{array}$ & $\begin{array}{c}48.227 \\
(18.245)^{* *}\end{array}$ & $\begin{array}{c}50.047 \\
(17.915)^{* * *}\end{array}$ \\
\hline $\mathrm{R}^{2}$ & 0.035 & 0.019 & 0.649 & 0.645 \\
\hline D.W. & 2.105 & 2.120 & 2.155 & 2.115 \\
\hline $\mathrm{F}$ & $(5,43)=0.310$ & $(3,45)=0.285$ & $(5,40)=14.810^{* * *}$ & $(4,41)=18.657^{* * *}$ \\
\hline SEE & 390.181 & 384.591 & 29.384 & 29.183 \\
\hline
\end{tabular}

Note: 1) Values in parentheses are the standard errors of the estimated coefficien

* indicate significance at the $1 \%, 5 \%$, and $10 \%$ levels, respect 75 number of observations

2) The values of D.W.1; and 4-D.W.1. with 5 explanatory vaspectively.

at the $5 \%$ significance level are 1.770 and 2.230 , sesthe $55 \mathrm{th}, 68 \mathrm{th}$, and 74 th affiliated

3) On the basis of the casewise diagnostics, the "(4)."

Table 6. The Elasticity of EaCH of DISPARITY and VRLI with Respect TO SHED $/ K^{1 \prime}$

\begin{tabular}{c|c|c|c}
\hline \multirow{2}{*}{$\begin{array}{c}\text { Ownership-Control } \\
\text { Disparity Variables }\end{array}$} & \multicolumn{3}{|c}{ Explanatory Variables } \\
\cline { 2 - 4 } & SHED/K & NA/K & CF/K \\
\hline DISPARITY & 0.340 & -0.492 & -0.162 \\
\hline VRLI & 0.255 & -0.389 & -0.148 \\
\hline
\end{tabular}

Note: 1) The number of observations for DISPARITY is 78 and those for VRLI is 49.

2) The elasticities are evaluated at mean values. For example, the elasticity of DISPARITY with respect to SHED/K evaluated at mean values is $0.714 \times($ mean of (SHED $/ \mathrm{K}$ ) mean of DISPARITY) $=0.340$. Mean value of each variable for $\mathrm{n}=78$ is summarized as; DISPARITY $=5(0.325, \mathrm{SHED} / \mathrm{K}=23.967, \mathrm{NA} / \mathrm{K}=66.5(14)$, and $\mathrm{CF} / \mathrm{K}=18.7 .12$. $\mathrm{Mean}$ value of (ach variable for $\mathrm{n}=49$ is summarized as; VRLI $=86.887, \mathrm{SHED}) / \mathrm{K}$ $=15.281, \mathrm{NA} / \mathrm{K}=75.293$, and $\mathrm{CF} / \mathrm{K}=21.380$.

In Table 6, we compare the elasticity of the ownership-control disparity index (DISPARITY) to the elasticity of the voting right leverage index (VRLI) with

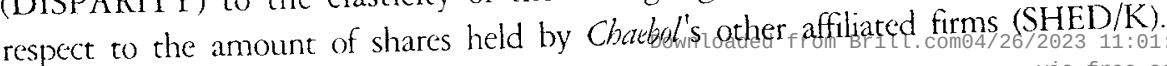


It is found that the ownership-control disparity index is more elastic than the voting right leverage index with respect to the amount of shares held by Chaebol's other affiliated firms.

\section{CONCLUSION}

We examine the relationship between the amount of shares held by Chaebol's other affiliated firms and the affiliated firm's ownership-control disparity. To this end, the ownership-control disparity equations are estimated with the ownership-control disparity index and the voting right leverage index as dependent variables, using cross-sectional data on 78 affiliated firms in Chaebols in 2005. These Chaebols are subject to a ceiling on the total amount of holding shares of other affiliated firms in Chaebol.

The amount of shares held by Chaebol's other affiliated firms (SHED), the amount of net assets (NA), the amount of capital (K), the amount of sales revenue (S), the amount of debt (D), and the amount of cash flow (CF) are used as explanatory variables in the form of ratio to the amount of capital (K). Results from the RESET specification tests and the estimated values of D.W. suggest that correct specifications are implied in each of the two ownership-control disparity equations for regression.

The estimation results with the ownership-control disparity index indicate that the increase in the amount of shares held by Chaebol's other affiliated firms deepens the ownership-control disparity. Therefore, the ceiling on the total amount of holding shares of other affiliated firms in Chaebol can contribute to reducing the ownership-control disparity. And the amount of net assets and the amount of cash flow mitigate the ownership-control disparity. The estimation results with the voting right leverage index are almost the same as those with the ownership-control disparity index.

We also find that the ownership-control disparity index is more elastic than the voting right leverage index with respect to the amount of shares held by Chaebol's other affiliated firms.

Overall, our empirical findings suggest that the ceiling on the total amount of holding shares of other affiliated firms in Chaebol can mitigate the ownership-control disparity. Thus this ceiling system can help protect the property rights of the minority shareholders and can contribute to desirable corporate governance.

\section{REFERENCES}

Breusch, T. S. and A. R. Pagan. 1979. A Simple Test for $r_{B}$ Heterosceddasticitity: 01:00AM 
and Random Coefficient Variation, Econometrica 47(5): 1287-1294.

Choi, Kang-Deuk and Hong-Bok Ahn. 2007. After Economic Crisis, An Empirical Study on Relationship among the Governance-Ownership Structure of Korean Chaebol firms, Accounting Policy and Firm Value: Focusing on an endogenous effect, Review of Business and Economics, Korean Industrial Economic Association, 20: $551-577$ (in Korean).

Dowrick, S. 1993. Estimating the Impact of Government Consumption on Growth: Growth Accounting and Optimising Models, presented at the Combined Economics Department and Associated Research Programs Seminarl Workshop series, University of Wollongong, New South Wales, Australia.

Gerdtham, U-G. and B. Jonsson. 1991. Conversion Factor Instability in Inter national Comparisons of Health Care Expenditure. Journal of Health Economics 10: $227-234$.

Kang, Chul Kyu and Jae Hyung Lee. 2007. The Effect of the Shareholdings of Other Companies by Chaebol on Corporate Investment: An Empirical Study. Review of Business and Economics, Korean Industrial Economic Association, 20: 1131-1160 (in Korean).

Kim, Pyung-Kee. 2007. The Effects of Cash Flow on Corporate Cash Management. Review of Business and Economics, Korean Industrial Economic Association, 20: 619-648 (in Korean).

Ko, Dongsoo, Hyunseung Cho, and Minsoo Park. 2006. The relacionship between the ceiling on the total amount of holding shares of other affiliated firms in Chaebol and firm investment, Research Report, KIET.

Pagan, A. and F. Vella. 1989. Diagnostic Tests for Models based on Individual Data: A Survey, Jounal of Applied Econometrics 4: S29-S59.

\section{ENDNOTES}

\footnotetext{
1 Under the ceiling on the total amount of holding shares of other affiliated firms in Chatobl, the Chaebol's affiliated firms with more than 6 trillion won of total assets are not allowed to hold shares of other affiliated firms in excess of $25 \%$ of their own net assets in 2005 .

2 SPSS will list these if you ask for "casewise diagnostics" under the statistics button. The removal of outliers from the data set under analysis can at times dramatically affect the performance of a regression model.

3 Choi and Ahn (2007) show that ownership-control disparity index is negatively correlated with asset, using Chatbol's 99 affiliated firms for the period of $200(0)-2003$.

4 These results are consistent with $\mathrm{Kim} 12(1)^{-}$is results.
} 